\section{French budget}

\section{Science pluses}

\section{Paris}

The French science budget really is on the up and up: FF 32,500 million $(£ 2,650$ million) in 1983, 28 per cent more in 1982 , according to figures released last week by the ministry of research and industry.

This figure, which includes all government civil research and development, must be corrected for inflation (now 12 per cent and optimistically projected to be 8 per cent next year). But even so the increase is impressive and seems even more remarkable when set against the present parlous state of the French economy, propped up last week by a $\$ 4,000$ million international loan, and against the average government budget increase for next year - a meagre 5 per cent in real terms.

How does Jean-Pierre Chevènement, the minister for research and industry, do it? From the left of the socialist party now in power, he appears to have formed a remarkable liaison with a man from the right, Jacques Delors, the finance minister, who is constantly urging budgetary restraint and the control of inflation. Both, it seems, are seized with a kind of constructive realism: they agree that France must renew and rebuild its wealth-generating industry, to which end science and technology are essential.

This is an economic objective, however, not a "scientific" one, and its implications run right through the 1983 budget. Moreover, Chevènement has stealthily adopted, without ever quite announcing it, a means of science funding akin to the British "Rothschild principle": the customer pays, and the contractor does what the customer wants, to the best of his ability. In France this is now called budget management "par programme".

The ministry identified seven major strategic areas, and four key technologies (called "programmes mobilisateurs" and "programmes de dévelopment technologique", see below). The only difference from Rothschild's historic adjustment to the accounting of British research council cash in 1972 is that, in France, no precise figure has been set aside for the research councils to manage by themselves.

The seven programme mobilisateurs are:

- Rational use of energy and diversification of sources

- Biotechnology

- Development of the electronics industry

- Science and technology for the Third World

- Research on employment and work conditions.

- Promotion of French as a scientific language, and the spread of scientific culture - The penetration of technology into industry

The four programmes de développement technologique are: Nuclear power; Space; Civil aeronautics; Oceans.
The whole sum, effectively, is in the hands of the customer - the ministry.

This shows up particularly clearly if the FF 32,500 million civil research budget is divided into two parts: money directly controlled by the ministries or sent to industry, and money "processed" through the grands organismes (on which French university and grands organismes researchers can exert the greatest pressure). The first category is more applied, and more easily controlled politically; the second more basic, and less easily controlled.

The easily controlled category includes: FF 1,500 million directly available to Chevènement for his own research priorities (up 29 per cent on this year); FF 1,800 million for industrial research support (up 78 per cent); and FF 7,200 million spent on research and development by other ministries under Chevènement's guidance (up to 65 per cent). Altogether, this category totals FF 10,500 million in the 1983 budget, compared with only FF6,500 million in 1982: a rise of 62 per cent. The remainder of the budget, sullied - from the political point of view - by the inertia of the grands organismes, amounts to FF 22,000 million, a rise of only 17 per cent on this year.

These global figures, however, conceal important different in treatment among the different grands organisms. Here it is also important to distinguish between money credited - actually to be spent next year - and authorized, which equals the credits plus sums, usually for capital equipment, which can be committed but not spent. A third accounting category is "ordinary spending", essentially salaries. All the figures so far given apply to the authorized sums plus ordinary spending, as this is the best long-term indicator.

In the 1983 budget, the most dramatic differences are in the credits, which for the grands organismes rise 26 per cent over the last year to FF 8,900 million. (The fact that authorizations rise only 16 per cent indicates perhaps that the ministry is taking care not to over-commit itself to basic research for 1984, should the French budget collapse entirely.)

Within these credits to the grands organismes, the Centre National de la Recherche Scientifique (CNRS), which does most basic research and has the greatest prestige, will see a 28 per cent rise in 1983 and - almost uniquely, a larger rise in authorizations: 36 per cent. CNRS will do well. INSERM, which supports medical research, gets a rise of 37 per cent in credits, but only 21 per cent in authorizations.

This year, Chevènement has been able to amass enough cash essentially to insulate basic scientists from the impact of technological priorities, which are appearing as additions to budgets rather than alterations. But whether this will be so next year (that is, in 1984) may depend on the performance of the French economy in the interim.
Council of scientific unions

Enter China

The admission of the People's Republic of China to the International Council of Scientific Unions (ICSU) was the highlight of this year's general conference, held last week in Cambridge, England. China will be represented by the China Association for Science and Technology (CAST).

During the past few years, science - a major casualty of the cultural revolution has been considerably rehabilitated in China. The prestigious journal Scientia Sinica has resumed publication and the admission of China to ICSU was so little in doubt that a seven-person delegate from Beijing was already in Cambridge, waiting for two days while a suitable formula was worked out. The main problem was to ensure the admission of CAST without excluding the academy in Taipei (Taiwan), whose contribution to science has of recent year been considerably larger than the modest size of the population would suggest.

Apart from excitement over the Chinese issue, which some delegates felt had become too political, this ICSU conference, like its predecessors, consisted largely of reports on continuing activities rather than startling innovations. There were no real controversies, even on such sensitive subjects as the storage of highlevel radioactive wastes on or near the Earth's surface; the main controversy was whether they should be so stored for 50 or 100 years. There was, however, general agreement that an ICSU-sponsored survey of nuclear war scenarios would be useful.

In the Committee on the Safeguarding of the Pursuit of Science, there were some sharp remarks on recent cases of Soviet Jews deprived of their academic degrees for political reasons. On the other hand, the case reported to the Committee for the Free Circulation of Scientists of the two Soviet scientists refused visas for an international conference in Australia in August was finally resolved, after an exchange of telexes, by a pledge from the Australians that no such difficulties would arise in the future for Soviet scientists wishing to attend multinational conferences in Australia.

A number of routine matters were brought to a satisfactory conclusion. The Committee on Science and Technology in Developing Countries (COSTED) was reorganized to give it a wider orientation (recently it has concentrated almost entirely on India). A long-term plan by the Committee on Publications and Communications (COPAC) for the establishment of an ICSU press was accepted, and COPAC was authorized to proceed to the projected first phase of that plan - the discussion of ways and means with the presses of member national academies and the like, as well as with commercial presses where academies do not have their own press. 